\title{
DEBATES ON RELIGIOUS STUDIES IN THE PHENOMENOLOGY PERSPECTIVE AND ITS CONTRIBUTION TO INTERFAITH TOLERANCE
}

\author{
Akhiyat \\ State Islamic Institute of Jember \\ Email: akhiyat9@yahoo.co.id
}

\begin{abstract}
The phenomenological approach in religious studies has played an essential role in uncovering the mysteries of religious experience. With the epoché concept, which refers to the meaning of "delaying all judgments", or it can be said as meaning with the intention of suspending an understanding, that is interpreted as "confinement" (bracketing), the researcher must temporarily let go of all his judgments or understanding of the phenomenon under study to obtain universal knowledge that is transcendental to the phenomenon of religion and experience the essence that they obtain. However, critics from experts for this phenomenological approach to religion still exist, in this case, summarized in three points: first, about the continuity of the phenomenology of religion as a philosophical tradition. Second, hidden theological assumptions or motives behind the phenomenological approach of religion. Third, what is the involvement of religious scientists in the public role as social scientists face current social and political realities or the challenges of religious scientists whether they accept the public role or do not face the reality of various problems faced by society.
\end{abstract}

Keywords: Religion Studies, Perspective, Phenomenology

DOI: https://doi.org/10.20414/ujis.v23i1.347

\section{Introduction}

RELIGION IS A SYMBOLIC expression that is diverse and is also a person's response to something that is understood as a universal value. The symbolic expression is the main characteristic in understanding the meaning of religion. Thus, the central theme of scientific research on religion is the fact of religion and its disclosure or in the simple language of efforts to make religion the 
target of research. The data used is obtained through observation of human life and religious habits when expressing religious attitudes in actions such as prayer, rituals, religious concepts, belief in the sacred, and so on. Although talking about the same thing, various disciplines observe and examine from certain aspects that are in accordance with their goals and reach. ${ }^{1}$

In religious studies to describe human religious phenomena, it is indeed not as easy and straightforward as many people usually imagine. Indeed, to show religion as "proper noun" ${ }^{2}$ such as Islam, Catholicism, Protestantism, Hinduism, Buddhism is straightforward, but the more fundamental thing is that there is no "abstract noun ${ }^{3}$ of all kinds. If there is no abstract form, as an ontological basis for a conversation, it is impossible for humans to mention the proper noun as a name for anything, because the abstract noun is the basis of the proper noun logic. From this, it can be understood that in the phenomenological approach to religion, it is similar to the approach to the plains of Pure Science. It can be understood that the focus of the phenomenological approach is limited to the search for "essence", "meaning" and "fundamental structure" from the experience of human religiosity. In the experience of human diversity, there is an irreducible

1 Mariasusai Dhavamony, Phenomenology of Religion, trans. Drikarya Religious Study Team (Yogyakarta: Kanisius, 1995), 21.

${ }^{2}$ In terms of "proper noun" religion is particular (certain, especially). Often in the meaning of religion adhered to by adherents, it is still solid "truth claim", because the logic built is "a way of speaking" is not based on "a way of reasoning." See, Mohamed Arkoun, Ayna Huwa al-Fikr al-Mu'āshir (Beirut: Dār alSaqi, 1992), 91-96.

3." An abstract noun is universal (an element of the universality of religion). In Husserl's language "something transcendental" through thinking that is oriented towards the search for fundamental ideas or the basic structure of a religion, it is hoped that the true nature of religious understanding can be achieved. Another term, in Islam with a "big I" (in which there is a message "peace"), in Christianity with "big K" or Protestant with "big P" (in which there is a message "love"). Not the other way around, in the Islamic sense of "small I", Christian with "small k, so is Protestant with" small p "in the form of a practical (particular) regulation that appears in the life outside of religion (skin). See also, Ibid. 
essence, and that is the fundamental structure of religious humans. ${ }^{4}$

On the other hand, phenomenology, which in fact, philosophical thought is used for Islamic studies and other studies. The application of phenomenology in various disciplines has hardly experienced many difficulties, not so in understanding religion. The difficulty comes from: first, the fact that religions are developing, so religion is the object of study that lives and develops typically. Second, religion is individual, subjective, inner; loyalty is the primary demand in religion. As a result, in religious studies, people often compare religions with their methods, while formulating moral excellence.

Religious studies, especially the phenomenology of religion that uses a set of interdisciplinary social sciences, provide valuable input to the treasures of Islamic science. This proves that religious studies are unique, perhaps the most difficult. The difficulty lies in the first fact, that if other sciences assume that they can distinguish clearly and straightforwardly between the role of "object" and "subject" in their study and academics, whereas in religious studies this is not possible. The involvement of the role of "subject" is very thick in religious studies, but there is the phenomenon of "object" beyond the subjectivity of the observer or the researcher exists. ${ }^{5}$

In phenomenological reduction, it is filtered about the reality of "object" and "subject". The object was investigated only to the extent that it was realized. The object is seen according to its relation to consciousness. Regarding the facts, no reflection or no statement was held. In reducing eiditis, the nature of the phenomenon is sought. One thing that is called essence is the basic structure which includes original content, all essential properties, all essential relations with consciousness and with other objects that are realized. To find the essence, filtered and cleansed all

${ }_{4}^{4}$ See, M. Amin Abdullah, Studi Agama: Nornativitas atau Historisitas? (Yogyakarta: Pustaka Pelajar, 2004), 23-35.

${ }^{5}$ M. Amin Abdullah, "Mempertautkan Ulum al-Din al-Fikr al-Islamy dan Dirasah Islamiyah" (Paper presented at the Workshop Pembelajaran Inovatif Berbasis Integrasi-Interkoneksi, Yogyakarta, 2008), 45. 
aspects which are merely accidental, unimportant, and only relate to individual objects. The transcendental-phenomenological reduction is a direction to the subject and regarding the occurrence of self-appearance, as well as regarding its roots in consciousness. The consciousness found in this reduction is the awareness of pure subjectivity or the same as self transcendental. Nevertheless, the self loses its transcendental status. The world is according to the existence of an individual community that is intersubjective. Therefore phenomenology is very necessary for the context of religious studies, although at the applicative level, there are still many different views about the facts in the academic environment.

\section{The Phenomenology Framework of Edmund Husserl}

Phenomenology comes from the Greek "phainein," which means "to show," the origin of this word gives rise to the word phenomenon, which means "something that arises." Or, phenomenology is considered "returning to the object itself" (back to the things themselves). This term was allegedly first introduced by a German philosopher, Edmund Husserl. However, according to Kockelmas, the term phenomenology was first used in 1765 in philosophy and is sometimes referred to in Kant's writings, but only through Hegel the definite technical meaning was built. ${ }^{6}$

For Hegel, phenomenology is concerned with knowledge as it appears to consciousness, a science that describes what is thought, felt and known by a person in his current consciousness and experience. The process led to the development of phenomenal consciousness through science and philosophy "towards absolute knowledge of the Absolute". ${ }^{7}$ Hegel's philosophy provided the basis for later religious studies. In his book, The Phenomenology of Spirit (1806), Hegel develops the thesis that essence (Wesen) is understood through the investigation of displays and manifesttations. The purpose of Hegel is to show how this leads to an understanding that all phenomena, in their diversity, are rooted in essence or fundamental unity (Geist or Spirit). This game of the

6 Clark Moustakas, Phenomenological Research Methods (London: Sage Publications Inc, 1994), 26.

${ }^{7}$ Ibid. 
relationship between essence and manifestation provides a basis for understanding how religion, in its diversity, can be understood as a different entity. He also, based on transcendent reality, which is not separate from but can be seen in the world, gives credence to the importance of religion as an object of study because of the contribution that can be given to "scientific" knowledge. ${ }^{8}$

Whereas, according to Husserl's formulation, phenomenology is a study of the structure of consciousness that allows those consciousness to refer to objects outside of itself. This study requires reflection on the contents of the mind by putting everything aside. Husserl calls this reflection type "phenomenological reduction." Because the mind can be directed towards nonexistent and real objects, Husserl notes that phenomenological reflection does not assume that something exists, but rather it is equal to "confinement of existence," that put aside the question of the real existence of the object in mind.

Husserl raises several important points. However, what later became a valuable methodological starting point for the phenomenology of religion was: epoché and eidetic vision. Epoché refers to the meaning of "delaying all judgments", or it is the same as "confinement" (bracketing). This means the absence of preconceptions that will affect the understanding taken from something. In other words, bringing the concepts and constructs of one's views to their investigations is seen as a damaging influence on the results. Eidetic vision is related to the ability to see what is actually there. He requires epoché action, introducing the capacity to objectively see the essence of a phenomenon, but also directs the issue of subjectivity of perception and reflection. He also considers the capacity to gain an intuitive understanding of a phenomenon that can be defended as "objective" knowledge. ${ }^{9}$

More details, Husserl when in the process of searching the scientific method, he emphasized the significance of the phenomenological method. He said that "the principle of all

8 Quoted in Clive Erricker, "Pendekatan Fenomenologis," in Aneka Pendekatan Studi Agama, ed. Peter Connolly, trans. Imam Khoiri (Yogyakarta: LKiS, 2002), 110.

${ }^{9}$ Quoted in Ibid., 110-111. 
principles" is that only direct intuition (by not using any mediator) can be used as the final criterion in the field of philosophy. What is given directly to us in the experience can be justified and considered as far as it is given. From there, Husserl concluded that consciousness must be the basis of philosophy.

Husserl's desire to find scientific truth in it was strengthened by efforts to underlie his philosophy as a "rigorous"10 science and in this science he gave the name phenomenology. However, the phenomenology that Husserl refers to as "reality" itself that appears. Consciousness always means awareness of "things" (real reality, not making up / subjective). In another perspective, it can be said that Husserl called it "consciousness according to its nature" to be intentional, i.e. intentionality is the essential structure of consciousness. Because consciousness is characterized by intentionality, the phenomenon must be understood as what appears. To say that "intentional awareness" is basically the same as saying "reality manifests itself". ${ }^{11}$ Thus, intentionality and phenomenon are two correlative principles.

Intensionality and phenomenal work processes through the constitution. The constitution is the process of the emergence of things that reveal or phenomenon of consciousness. That is to say, "constitution" is an activity of awareness that allows reality to appear. The real world is constituted by consciousness, but it does not mean that consciousness carries out or causes the world along with the distinctions contained in it, but only that consciousness must be present in the world so that world appearances can take place. ${ }^{12}$ Thus, the truth basically cannot take place on him, which is detached from consciousness. The truth is the real world must take place in the process of consciousness. This theory does not have the freedom to let the truth go without control by the owner. The universal truth here is almost invisible, to say nothing because the truth is always a connection between consciousness or

10 "Rigorous," which is a science that does not contain an element of doubt (apodictic) and does not allow further development and change (absolute). See, Jan Hendrik Rapar, Pengantar Filsafat (Yogyakarta: Kanisius, 1996), 119.

${ }^{11} \mathrm{~K}$. Bertens, Filsafat Barat Abad XX: Inggris-Jerman (Jakarta: Gramedia Pustaka Utama, 1990), 99.

12 Ibid., 120. 
intentionality and reality. Bertens gave an example referred to by the constitution by Husserl as follows:

I see mountains, for example. But actually what I see is always a perspective from the mountain: I see mountains from the east or north or from above and so on. But for perception, mountains are the synthesis of all those perspectives. In perception, the object has been constituted. But the same thing applies to every consciousness actus, also for intellectual activities. For example, I think of Pythagorean propositions. I can repeat it continuously, and every time I look at the same "Pythagorean proposition". That is only possible because of a constitution by consciousness. ${ }^{13}$

Towards the end of his life, Husserl's thoughts experienced a change in the historical direction in consciousness and reality. Fenomenon is not something static, but it is a process that follows the path of its historical development. What Husserl wants to emphasize here is that when we want to understand the reality or phenomenon of modern society, we need to uncover the history of premodern society to know deeply about modern society.

The activities carried out by Husserl, are none other than intended to build knowledge of rigorous, which is a science that does not contain an element of doubt (apodictic) and does not allow further development and change (absolute). However, when rigorous science is challenging to achieve in the real world because objects cannot express their pure nature, in accordance with pure reality without awareness, then Husserl offers three stages of reduction (filtering) as stated by Rapar. ${ }^{14}$ The first stage, the phenomenological reduction, is done by filtering the first experience directed at the existence of phenomena. Another term is also called "confinement" (epoché). It is interpreted as a delay in assessment. Only by confining beliefs and judgments based on an untested natural view can a phenomenologist know the phenomenon. Sensory experiences are not thrown away but are suspended in the screening process so that all forms of prejudice and prejudice are eliminated both traditional and religious beliefs. The objectivity of knowledge becomes a priority so that phenomena are sought to express its essence purely by eliminating the elements of subjectivity. In this context, a seeker of the truth of

${ }^{13}$ Ibid.

${ }^{14}$ Rapar, Pengantar Filsafat, 120. 
science is demanded neutrality and wholeness in capturing a phenomenon that reveals itself. That is, the phenomenon here is left to speak for itself, and at the same time, there is a process that follows it, that is a form of consciousness from one who observes.

Second, the eidetic reduction is to find eidos, the nature of hidden phenomena. There is another expression called eidetic vision. Is cognitive understanding (intuition) about essence, often described as eidetic reduction, which contains the notion of "universal essences". These essences express the "essence" (whatness) of something, important and unchanging characteristics of a phenomenon that allows us to recognize phenomena as certain types of phenomena. Observation of the nature of phenomena is carried out carefully in order to reveal the true nature of the phenomenon. In this process of observation, the observer needs to direct himself to the most basic content and the essential things. This step is a further process from the first step. This step carries out a careful review of an object that is observed up to the very basic things. However, this step still has a weak point because an observer still puts his awareness on an object, so that the truth is still in perspective. Or as far as the observation of an observer from where he observed it.

Third, the transcendental reduction is to set aside and filter all relationships between observed phenomena with others. For example, the observed phenomenon is ourselves. We must realize that we ourselves always have relationships with others, who are outside ourselves. Such relationships make us always in certain situations, such as we are eating, writing, bathing, and so on. Such experiences are clearly things that must be set aside because they are part of empirical awareness. The transcendental reduction must find pure awareness by setting aside empirical awareness so that self-awareness is no longer based on the connection with other phenomena. The self-awareness that is free of empirical awareness overcomes all experience is transcendental. In this level, an observer has arrived at a complete level of observation that overcomes a perspective that is still perspective. That is, the form of truth in science which is only a perspective of "the truth so far" has been overcome by means of the integrity of the view on a 
situation. Especially when the object being examined is outside of itself.

In Husserl's thought, this transcendental reduction has a central position at the end of his life. He put it as an effort to overcome the empirical awareness and as a next step is to build awareness that is non-empirical (transcendent). So here we find a scientific work process that correlates material reality with consciousness.

\section{Phenomenology of Religion}

The main focus of religious phenomenology is the aspect of religious experience, by describing or describing religious phenomena consistently in the orientation of the faith or belief in the object under study. This approach sees religion as a different component and is carefully studied based on a religious tradition to gain understanding in it. Religious phenomenology arises in an effort to avoid narrow, ethnocentric and normative approaches by attempting to describe religious experiences accurately. ${ }^{15}$

A method is adopting the procedures of epoche (suspension of previous judgments) and eidetic intuition to see the meaning of people who are appropriately responding to being unrestricted values from them. ${ }^{16}$

According to Noeng Muhadjir, ontologically the phenomenological approach in religious research recognizes four truths (sensual, logical, ethical, transcendental). ${ }^{17}$ It's just that transcendent truths are distinguished between human truth and divine truth. Divine truth is obtained by interpreting and developing its meaning, but still unable to reach its substantive truth. ${ }^{18}$ In addition, according to him, if positivism emphasizes

${ }^{15}$ Anonym, "Phenomenology of Religion," Wikipedia, 2019, accessed February 18, 2019, https://en.wikipedia.org/wiki/Phenomenology_of_religion.

${ }^{16}$ James L. Cox, Expressing the Sacred: An Introduction to the Phenomenology of Religion (Harare: University of Zimbabwe, 1992), 24.

17 Sensual: based on human sensory ability, Logic: based on the sharpness of thinking in giving meaning to an indication, Ethics: based on the sharpness of reason in giving meaning to an indication (although all that range is not complete). See Noeng Muhadjir, Metodologi Penelitian Kualitatif (Yogyakarta: Rake Sarasin, 1989), 19.

18 Ibid., 183-185. 
objectivity following the methods of natural sciences (natural sciences) and free of value (value free). In the scientific world, this phenomenological theory will contribute a value bound theory, which is currently a theory that is widely used by contemporary thinkers as a "critical theory" as a canter for positivistic theory. So, phenomenology has a foundation and values-bound is associated with values such as humanity and justice. ${ }^{19}$

Some figures who have played a major role in developing this approach include Pierre Daniel Chantapie de la Saussaye (born 1848) "Lehrbuch der Religionsgeschichte" translated in English "Handbook of the History of Religion", William James "The Varieties of Religious Experience: A Study in Human Nature (1902), Rudolf Otto "The Idea of the Holy" (1923), Gerardus Van der Leeuw "Phenomenologie der Religion" (1933) translated in English "Religion in Essence and Manifestation" (1938), Mircea Eliade " Patterns in Comparative Religion (1959) "The Sacred and The Profane" (1959), William Brede Kristensen "The Meaning of Religion" (1960), Smart Ninian "The Religious Experience of Mankind" (1971) "The Science of Religion and the Sociology of Religion (1973), Jacques Waardenburg "Classical Approaches to the Study of Religion" (1973) and Wilfred Cantwell Smith "The Meaning and The And of The Religion" (1978). In this paper, a glimpse of some of the characters' thoughts is briefly revealed.

\section{Pierre Daniel Chantepie de la Saussaye}

Saussaye uses phenomenology of religion as a comparative study in which the way it works is by classifying systematically different types of religious phenomena. Saussaye divides religion into two research areas, namely the essence and manifestation as Hegel's thought. In this case, he uses the history of religion to be then analyzed based on philosophical concepts. But Saussaye was criticized for using more historical analysis and only focused on religious rituals and did not use a philosophical approach. ${ }^{20}$

\footnotetext{
${ }^{19}$ Ibid., 185.

${ }^{20}$ Erricker, “Pendekatan Fenomenologis," 113.
} 


\section{William Brede Kristensen}

In Kristensen's view, the phenomenology of religion is a special branch, discipline or method in religious studies. If Saussaye's phenomenology is more influenced by history, Kristensen argues that the history of religion and philosophy are interconnected and influence as a complement to phenomenological studies. As Saussaye, Kristensen argues that the main purpose of religious phenomenology is to look for "meaning" religious phenomena. It's just that Kristensen added that the search for the meaning of religious phenomena is in the context of each person's faith. Kristensen also argued that it was not enough just to classify or classify phenomena as understood by each religious tradition, but also expressed in an understanding. ${ }^{21}$

\section{Gerardus Van der Leeuw}

In his criticism of Kristensen, Van der Leeuw saw understanding as a subjective aspect in phenomenology which is inherently (unified) intertwined from the objectivity of a manifestation. Van der Leeuw correlates subjective experience, expression and understanding with the three objective levels of the apparition, namely the concealment relativity, the relative transparency and gradual progression towards manifestation. The phenomenology of Van der Leeuw's religion is based on three fundamental parts, namely: God - man - the relationship between God and humans. In this case, the relationship between God and humans is the central issue that underlies Van der Leeuw's thinking. ${ }^{22}$ According to Van der Leeuw, phenomenology seeks or observes phenomena as they appear. In this case, there are three principles included in it: (1) something is manifested, (2) something appears, (3) because something looks right then it is a phenomenon. The apparition shows the similarities between what appears to be received by the observer, ${ }^{23}$ without making modifications. Allowing that phenomenon to speak for itself, so

\footnotetext{
${ }^{21}$ Ibid., 114-115.

22 Ibid., 115.

${ }^{23}$ Jacques Waardenburg, Classical Approach to the Study of Religion (Paris, Mouton: The Hague, 1973), 412.
} 
that by phenomenologists, phenomenology is seen as rigorous science. This seems to be in line with the "principle" of science, as stated by J.B. Connant, that:

"The scientific way of thinking requires the habit of facing reality quite unprejudiced by and any earlier conceptions. Accurate observation and dependence upon experiments are guiding principles". ${ }^{24}$

From the discussion of several figures described above, at least the phenomenology of religion can be mapped in three major currents, namely: (1) religious phenomenology is interpreted as an investigation of phenomena or objects, observable facts and religious events; (2) phenomenology is interpreted as a comparative study and classification of types of different religious phenomena; and (3) religious phenomenology is defined as a branch, discipline or special method in religious studies.

\section{Criticism of the Phenomenology of Religion}

In this discussion, debates or criticisms are summarized from Chapter 7 of James L. Cox's book. ${ }^{25}$ This debate will be divided into three themes, namely (1) the continuity of phenomenology as a philosophical tradition; (2) theological motives; (3) and the involvement of religious scientists socially in society.

Gavin Flood's criticism of the Continuity of Phenomenology as a Tradition Philosophical.

In this study, the topic of discussion was the criticism of Gavin Flood about the continuity of phenomenology as a philosophical tradition that became the basis of the development of religious research. According to Flood, ${ }^{26}$ the method introduced by phenomenologists, who tried to limit the possible damaging biased influences, described by Kristensen and Parrinder as applications of evolutionary theories to religion and culture, and

${ }^{24}$ James B. Connant, Modern Science and Modern Man (Garden City, New York: Doubleday Company, 1954), 19.

25 James L. Cox, A Guide to the Phenomenology of Religion: Key Figures, Formative Influences and Subsequent Debates (New York: T\&T Clark International, 2006).

${ }^{26}$ Ibid., 214-215. 
by Eliade and Smart as reductionistic tendencies in science social sciences, based on philosophical theories that incorporate deeper, but simpler biases into the way a knowledge is acquired and regulated. Assuming universal human experience at the heart of all religions that are cognitively understood (intuition) by "separate subjects", phenomenologists ignore, or at least minimize, the importance of cultural, historical and social contexts. In addition, the "epistemic privilege" given to researchers remains hidden because it hides the power relations between researchers and the community under study. By carrying out phenomenological confinement to eliminate all types of prejudice, religious scientists paradoxically still control knowledge and thus make rules for interpreting religious phenomena. This makes phenomenology, at least, vulnerable to the accusation that it is actually spreading a method of maintaining power over the object of academic study, although there is a virtual agreement among phenomenologists that their personal religious experience gives privileged access to the mind of a religious practitioner. This final claim to religious views, which is not available to other scientists, strongly implies the "theological agenda" behind religious phenomenology and then causes tension between theology and academic studies of religions.

Donald Wiebe's criticism of the theological motives of van der Leeuw, Eliade and Smart

Wiebe accused the three figures of having theologized academic studies of religions. Van der Leeuw, for example, insists that every scientist must depart from a cultural orientation to life, which is very similar to the position of personal belief, and emphasizes that because scientists are located in a specific context, the scientific activity cannot be separated from "religio-cultural search "The scientist himself. According to Wiebe, van der Leeuw in this matter is childish and misleading, because that view prevents the researchers' biases from being recognized and clarified critically. This argument destroys the academic goals it supports precisely because it "ignores critical differences between religion and scientific-academic studies of religion". This means that van der Leuuw, who tried to move the Dutch tradition that 
Chantepie de la Saussaye and C. P. Tiele had begun to transcend theology, actually did the opposite by redirecting it to theology. Wiebe said, "With van der Leeuw ... the study of religion not only does not move beyond the stages that scientific discipline has achieved in the Netherlands, but rather returns to the initial theological approach - an approach which is tantamount to subversion of religious scientific studies." 27

Simple, the critique of van der Leeuw's religious phenomenology, as Allen explained, ${ }^{28}$ is based on the assumption that his phenomenological approach is based on a number of theological and metaphysical assumptions and assumptions; often subjective and speculative; ignoring the cultural and historical context of religious phenomena and less valuable for empirical-based research.

Against Eliade, Wiebe attacked his hermeneutical method, which he referred to as "an attempt to restore the abandoned values and transcendent meanings that had been given to its adherents by those traditions." This view is supported by Eliade's assertion that forms ancient and primitive religions are paradigmatic for religious life in general because they reveal "fundamental existential situations that are directly relevant to modern humans." Wiebe saw Elliade's interest in ancient and primitive traditions not departing from a scientific approach to religious studies because this "would require reductionistic distortion of the truth of religion and hence, the distortion of the truth about religion." Wiebe assumed that Elliade's antireductionistic position concealed the "veiled theological agenda". To support this, he quoted Elliade's view that by interpreting religion "religiously", scientists contributed to "saving" "modern humans". "Knowledge of religion" thus becomes "religious knowledge", which in Wiebe's view confirms Elliade's hermeneutic method "indistinguishable from religio-theological."29

27 Ibid., 218.

${ }^{28}$ Douglas Allen, "Phenomenology of Religion," in The Routledge Companion to the Study of Religion, ed. John R. Hinnells (London and New York: Routledge, 2005), 193.

${ }^{29}$ Cox, A Guide to the Phenomenology, 218-219. 
Both van der Leeuw and Eliade assert that a religious person recognizes the existence of transcendent power or supernatural reality as a source of human religious experience. They assert that this is true for believers, they even go beyond this statement by asserting that the transcendent forms an ontological reality, in which in some cases scientists must experience it personally if a pure understanding of religion is to be achieved or communicated. Thus, van der Leeuw and Eliade are vulnerable to the accusation that their phenomenology is similar to religious theology..$^{30}$

Similarly, the ideas of Ninian Smart, according to Wiebe, when carefully analyzed, also gave rise to the same theological assumptions behind the phenomenology of religion. This was evident in his refusal to follow Peter Berger's "methodological atheism" because of the reason that it might hurt the faith community. Smart also insisted on the view that "studying religion" and "feeling the living forces of religion" not only can go together but "must walk together if the study of religion is expected to enter into a promising new era." this "is more likely to enter a religio-theological study of religion from which the scientific study of religion first appeared." Wiebe investigated what he considered the ambiguous description of Smart because it included questions about religious truth, which surpassed scientific interests, even though Smart said that religion is very different from theology. By raising the issue of religious truth, Smart is actually rebuilding the initial ties between academic studies of religion and piety. Smart's return to the theological perspective, according to Wiebe, is confirmed by the way he faces epoché (confinement). What is called Smart with "confinement of expression" conversely provides space for scientists to incorporate into delayed judgments the feelings expressed by adherents of religion, without supporting or validating those feelings. At this point, said Wiebe, Smart position ambiguity arises. If religious scientists aim not only to gain knowledge about religions but also express their beliefs about religious values and sentiments, then

${ }^{30}$ Ibid., 219. 
something more than religious knowledge will be contained, if not theology, at least metaphysics. ${ }^{31}$

\section{Public Role of Religious Scientists}

Mc Cutcheon is of the view that there are two problems carried out by religious scientists. First, they insist on the autonomy of their scientific disciplines, and this influences the act of separating institutional studies from other disciplines at the university. By determining the focus of religion as unknown, nonhistorical, holy-transcendent, Eliade and other phenomenologists have given up their rights to make comments about social and political issues. This arises not only from the theology of religious studies but from the assumption clearly stated by Eliade, that what is religious is good, healthy, positive and saving. Scientists who think that means it has lost its critical capacity to comment on the social reality of religion as a factor that contributes to various kinds of human actions, both positive and negative, including the relationship between religion and violence. Second, the description of religious data and the offer of interpretation only in ways that can only be affirmed by believers. Mc Cutcheon equates this method with "reflexive autobiography" which reduces the role of scientists only as reporters who repeat insider claims that are less important. ${ }^{32}$

The theory that the heart of religion is "personal faith", "supernatural", "holy" or "transcendent" leads to a very individualistic interpretation of religion which, according to Mc Cutcheon, lies in the root of the problematic distinction between religion and the world (secular). The dichotomy of the secular religion is based on the assumption that religion belongs to the private space. Religion, according to Mc Cutcheon, is explained as an independent variable that occupies a clean space for a pure and personal moral viewpoint, which opposes and saves a messy political and economic world.

The challenge of religious scientists today is whether they will accept the public role or not? The public role here is not practical

\footnotetext{
${ }^{31}$ Ibid., 220.

32 Ibid., 228.
} 
involvement with social and political issues, but as a critic who unmasks the "mechanism of power and control". This is applied first to the way in which religions are studied and refers to selftesting that is critical of methods and theories and religious studies. In the public sphere, scientists question "self-evidences", raise "intellectual freedom" and, by collaborating in crossdisciplinary ways with other scientists who use methods taken from their fields of study, identify ideological strategies that homogenize and which is so essential for the formation and regulation of the human community. Mc Cutcheon calls this role "cultural criticism." 33

Meanwhile, on the other hand, David Chidester, who did not directly confront the problem of socially involved religious scientists, explained that the social, historical and political contexts in religious studies influenced scientific interpretations and determined the categories through which they were filtered. He underlined the fact that religious studies look very different when viewed from the perspective of marginalized groups rather than within the academic power structure that prevails in Western universities.

He showed that the findings of "comparative religious experts" became influential tools for colonialism to establish and carry out "local control" by forming discourses about others that strengthened the colonial policy. Attitudes towards indigenous people change, from not having religion, adhering to ancient religions, to religion which cannot be equated with Western religion. In each case, these interpretations are to serve colonial interests.

For this reason, according to Chidester, we cannot understand the creation of the category of "religion" outside the colonial context in which power relations are installed and strengthened by the ideological construction of "the other". Based on this line of reasoning, religion as a Christian-Western finding should be understood not as a phenomenological error in category formation, but as a result of historically inspired and colonially

${ }^{33}$ Ibid., 229. 
inspired categories of power: high and low, civilized and primitive, central and periphery.

\section{James L. Cox's Response to The Debate}

According to Cox, debates about the philosophical continuity of the phenomenology of religion should be put in terms of subject-objects, or whether they must be understood narratively or dialogically. In this case, Flood's contribution comes from the emphasis on the inclusion of the faith community's perspective in the interpretation given by scientists about the faith community. Flood attempts to go beyond this by asserting that empathy actually perpetuates the difference between subject and object. In Cox's view, as long as the rules used by academic research are applied, the best thing scientists can achieve is a kind of radical empathy, rooted in self-reflection, but which recognizes the fundamental distinction between "self" (researchers) and "others " (object of research). This fact does not preclude dialogue because scientists must walk according to a clear commitment to scientific rationality, which goes hand in hand with the religious commitment of the community studied by scientists.

Cox follows the use of epoché which is loosely applied, by adopting a position of self-reflection, and commitment to community involvement in every interpretation given, so that the phenomenon can be possible to speak for himself. In this way, the task of interpretation comes from a combination of scientific selfreflection and empathy. ${ }^{34}$

Regarding the second debate, Cox said that religious studies include theology as part of its area of study. Theologians, at least in one definition, are practitioners. The study, analyze, interpret, generally in one tradition, the meaning of what is maintained by tradition. Religious scholars regard theology as ways in which some communities reflect alternative reality. In other words, theology, such as rituals, morality, myths, scriptures, community, law and art, forms part of the data that is used as a basis for religious study activities. This is not an affirmation of a position of

\footnotetext{
${ }^{34}$ Ibid., 234-235.
} 
superiority but only determines quite different roles for religious and theological studies. ${ }^{35}$

For this reason, Cox opposes efforts to encourage religious studies into theology by definition or place it in cultural studies. Cox remains unsure of the arguments given by Wiebe and Fitzgerald and counteracts that what we do in the phenomenological study of religion, as an analysis and interpretation of the community that institutionalizes behaviour around trusted alternative realities, is closely related to what is done in science social science, and not the same as other social sciences. Religious studies, in his view, live side by side with theology in the university department as a historical event, and not, as the new anti-religious wave says, as part of a deep ideological commitment to a transcendent reference. Based on this line of thought, it is possible to be loyal to the position of classical phenomenology that religious studies can be non-theological and non-reductive to any social sciences. ${ }^{36}$

Regarding the issue of the involvement of religious scientists on social issues, Cox agreed with McCutcheon that a religious scientist needs to play a public role, in the sense of "as a critic, not an administrator". As someone who has the ability and skills to analyze religious contexts, scientists must bear the responsibility to apply this to important issues that affect society. This means that the role of scientists as public criticism never takes place in a way that is independent of the social context. Here the role of scientists in addition to describing social processes originating from the institutions of power, both religious and secular, and identifying what influences these processes give to religion and spiritual experience in contemporary contexts, also removing harmful practices in that community. In this way, scientists may reveal structures of power that destroy religion through an individual process of radicalization, and at the same time may find different types of authority based on strong political and economic interests. By interpreting religion as an authoritative transmission of tradition in social contexts, religious scientists are given

\footnotetext{
${ }^{35}$ Ibid., 238.

${ }^{36}$ Ibid.
} 
important analytical methods through which they can offer an enlightened public comment and provide sharp social criticism. ${ }^{37}$

\section{Operational Steps of Phenomenology of Religion}

There are at least six steps or stages of the phenomenology approach in religious studies offered by Geradus Van der Leeuw in his book "Religion in essence and manifestation: A study in the phenomenology of religion". ${ }^{38}$

1. Classification of religious phenomena in their respective categories such as sacrifice, sacraments, holy places, holy times, words or scriptures, festivals and myths. ${ }^{39}$ This is done to be able to understand the value of each phenomenon.

2. They are interpolating in the personal life of the researcher, in the sense that a researcher is required to participate in blending and participating in a religious study to gain experience and understanding in himself.

3. Doing "epochè" or delaying the assessment (borrowing the term Husserl) with a neutral perspective.

4. Look for structural relationships of information gathered to obtain a holistic understanding of the deepest aspects of a religion.

5. These stages, according to Van der Leeuw will naturally produce an original understanding based on "reality" or the manifestation of a revelation.

6. Phenomenology does not stand alone (operate in isolation) but is related to other approaches to maintain objectivity.

${ }^{37}$ Ibid., 240-241.

${ }^{38}$ Emeka Charles Ekeke and Chike Ekeopara, "Phenomenological Approach to the Study of Religion: A Historical Perspective," European Journal of Scientific Research 44, no. 2 (August 2010): 271.

${ }^{39}$ In mapping Atho Mudzhar, scripture or religious texts and symbols, adherents, leaders or religious leaders (attitudes, behaviors and appreciation), rites, institutions, and worship (prayer, fasting, hajj, marriage and inheritance), tools (mosques, churches, bells, caps and so on). See Atho Mudzhar, Pendekatan Studi Islam dalam Teori dan Praktik (Yogyakarta: Pustaka Pelajar, 2007), 13-14. 


\section{Black and White behind the Phenomenology of Religion}

Phenomenology of religion is a development movement in thought and research where researchers try to understand humans and classify phenomena specifically including religious phenomena. Some points that are considered as the positive side of religious phenomenology include ${ }^{40}$

1. Phenomenology of religion is oriented to descriptive factual, where it is not concerned with evaluative evaluation but accurately and accurately describes a religious phenomenon such as rituals, symbols, worship (individual or ceremonial), theology (oral or written), personal which is considered sacred, art etc.

2. Not trying to explain the phenomenon described, especially standardizing universal laws to predict future religious issues, but to seek adequate understanding of every religious issue.

3. Comparisons in a limited sense that compare various religious traditions, but phenomenology does not attempt to equate or favour one particular religious tradition.

4. Avoid reductionism, in the pure sense of understanding religious phenomena in terms of sociology, psychology, anthropology and economics alone regardless of the complexity of human experience, imposing social values on transcendental issues and ignoring the unique intentionality of the perpetrators of religious traditions.

5. Postpone questions about truth, in this case, to develop insight into the deepest essence of a religious experience. Phenomenology seeks to get involved or participate directly to gain a genuine understanding of empathy.

6. Finally, develop the essential structure and meaning of a religious experience.

Apart from some of the advantages of the phenomenological approach, there are some difficulties in understanding the essence of religious experience and manifestation. In this case, some criticisms of the phenomenology of religion include:

1. Descriptive role. Phenomenology of religion claims that its approach is purely descriptive which is resistant to the

${ }^{40}$ Ekeke and Ekeopara, "Phenomenological Approach," 272-273. 
intervention of researchers, but it is not impossible that a phenomenologist has the interests of certain purposes and in controlling the data and methods used. In this case, it is not appropriate if phenomenology is claimed as a purely descriptive approach.

2. Seeing religious events, regardless of their historical roots. Phenomenology of religion is considered to tend to treat religious phenomena in historical isolation as if history is not needed in determining the relevance of the facts of phenomena to religious practitioners. In practice, often the phenomenology of religion is not able to contextualize religious phenomena studied.

3. The role of intuition. The difficulty of the researcher, in this case, is determining the right and acceptable side. The terms "objective" and "intuition" are contradictory, especially when using intuitive data to verify within the objective area.

4. The issue of empathy. There are fears of religious conversion because of demands to participate directly in religious practices and rituals.

Contribution of the Phenomenology Approach and Its Implementation to the Study of Religion for Interfaith Tolerance.

Apart from the various philosophers' debates in approaching religion as material for their studies, at least the phenomenological approach to studying religions will have positive feedback for religious tolerance. Especially in the midst of globalization that continues to erode harmony among religious communities, whether from the Islamic, Christian, Catholic, Buddhist, or other non-Muslim communities. The development of religious studies through a phenomenological approach can be said to be able to open a new veil, discourse and nuances between religious believers. Because not all believers, both Muslim and non-Muslim are able to reach complicated and complicated philosophical thoughts.

With the study of religion through a phenomenological approach as practised by religious scientists, it can at least contribute to philosophical thinking in interpreting and 
understanding the religions of others. When the community of interfaith believers has a common ground on the understanding of religion held by other adherents, surely they can respect and respect each other's religious beliefs. At a minimum, the concepts of equality will be used as references and references as a sign of collective collectivity among religious believers to maintain harmony. Starting from the role of the state, religious leaders, religious scientists, and each religious community.

As can be traced from the historical traces of the tradition of Western scholarship in the field of religious studies during the nineteenth century lacking or even not giving adequate and comprehensive attention to the study of religion, especially Islam. As a result, its contribution to the growth of knowledge about Islam, society and its religious traditions is very small. In addition, the developing oriental tradition is also considered to produce constructs and distortive images of Islam. In fact, this problem is also exacerbated by the fact that researchers (scholars) cannot be free from the background or ideological interests which greatly influences the resulting understanding.

This problem is caused partly by the tradition of orientalism, which places more emphasis on the philosophical and historical methods or approaches. Both of these methods are considered inadequate to understand religious traditions in an authentic and empathic way because they look more at external aspects of religion. During the nineteenth and early twentieth centuries, the study of religions was carried out using a partial and compartmental approach and emphasized only certain aspects of a religious tradition. Although an anthropological approach with participatory and archeological observations began to emerge, historical and philological approaches are still very dominant.

It was only after World War I that there was a strong interest among scholars (scholars) to study religion substantially and to find approaches that allowed religion to show authentic expression without intervening in personal values from religious research scholars. This situation is driving the growth of new approaches in the study of religions, including Islamic studies, namely the phenomenology approach. This new development is 
inseparable from the emergence of discipline or approach called the "phenomenology of religion".

Phenomenologists apply the method of explanation (verstehen) to various religious manifestations in all cultures. ${ }^{41}$ With this method, scholars will avoid judgment (judgment) of the values and truth of the religious data under study. The aim is to capture the essence (eidetic vision) that is behind religious phenomena. ${ }^{42}$ What is produced by the phenomenological approach is very important to make a methodological theory of consequences for the long term.

The phenomenological approach places religious experiences in response to deeper realities. However, they cannot be described. In this case, religion is seen not as a stage in evolutionary history, but rather as an essential aspect of human life. ${ }^{43}$ In other words, this approach seeks to bridge the gap and tension between the "historical-empirical-particular" dimension of religions and the fundamental and universal-transcendental aspects of humanity. The phenomenological approach puts emphasis on the expression of the role of meaning and religion in the lives of adherents of the religion. ${ }^{4}$

One important component in this approach is the verstehen method which presupposes that "people throughout society and the historical environment experience life as meaningful and they express this meaning in patterns that can be seen so that they can be analyzed and understood. This "verstehen method" was developed in the nineteenth-century hermeneutic tradition, especially in the study of culture (Geisteswissenschaften) which was driven by, among others, Wihelm Dilthey (1833-1911). ${ }^{45}$ Not

${ }^{41}$ See, Heddy Shri Ahimsa-Putra, "Fenomenologi Agama: Pendekatan Fenomenologi untuk Memahami Agama," Walisongo: Jurnal Penelitian Sosial Keagamaan 20, no. 2 (2012): 271-304, http://journal.walisongo.ac.id/index.php/ walisongo/article/view/200.

42 Richard C. Martin, Approaches to Islam In Religious Studies (Michigan: University of Arizona Press, 1985), 7.

${ }^{43}$ Ibid.

${ }^{44}$ Martin, Approaches to Islam, 7.

45 About hermeneutic as a method, philosophy and criticism, see Josef Bleicher, Contemporary Hermeneutics: Hermeneutics as Method, Philosophy and 
substantially different from the approach is the approach developed by Wilfred Cantwell Smith, religious and Islamic studies expert from McGill University. Smith stated that the object of the scientific study of religion (Islam) is the faith (faith) that is believed by Muslim individuals in the context of real life. Furthermore, Smith distinguishes two areas of inquiry: the beliefs of religious adherents and the cumulative traditions in which these beliefs arise. He argues that (religious) texts actually only depict some of these faiths, and reading of these texts will fail to understand Muslim faith if the resulting explanation differs from what is intended by Muslims themselves. ${ }^{46}$

Therefore, an investigation of the interrelation between these two religious aspects will provide an adequate understanding of the phenomenon of religion as a whole. With this approach, Smith intends to show that the study of religion is very complex, and cannot be reduced only to a conceptual abstraction in the minds of religious researchers. He emphasized the often changing character of religion and the importance of linking various types of inquiry to be fair to the insider's perspective and the goals of the social sciences themselves. ${ }^{47}$ One excellent example of the application of the phenomenological approach in Islamic studies can be seen in Henry Corbin, a French scholar who studies philosophical, Iranian and Shi'a traditions. ${ }^{48}$ In this context, phenomenology can be understood as "unveiling or exposing to view something that was hidden" (revealing or revealing to see something hidden). ${ }^{49}$ This approach is also called the hermeneutic approach to religion (Shi'ah Islam in Iran). Corbin considers it essential to place himself in their place (object) understudy, to make their experiences, perceptions and reactions as norms to explain the spirituality he (researchers) is interested in. The scholar must be a "guest in the spiritual realm of the people being studied and becoming that

Critique (London and New York: Routledge, 1980), 19, 25, 27, 47.

${ }^{46}$ Martin, Approaches to Islam, 9.

${ }^{47}$ Erricker, "Pendekatan Fenomenologis," 90.

${ }^{48}$ Charles J. Adam, "The Hermeneutics of Henry Corbin," in Approaches to Islam In Religious Studies, ed. Richard C. Martin (Tucson: The Arizona State University Press, 1985), 129-150.

49 Ibid., 143. 
nature as his own. ${ }^{50}$ Phenomenology, according to Corbin as quoted by Adams, is the key to the esoteric side of Islam. It is a method that unlocks secrets hidden from other realities, and in this role, phenomenology is the same as hermeneutics regarding the basic and profound nature of Islamic spirituality. Corbin's phenomenology or hermeneutics aims to demonstrate the "meaning" of the exoteric reality believed by Shi'ites. Hermeneutics or "phenomenology of spirit" in Corbin's view are the teachings of the Imams (Shi'ah) because it is they who demonstrate the secret meaning of revelation, but who live and continue to grow in society. ${ }^{51}$

Here it appears that Corbin's phenomenology is different from the phenomenology that has been used in religious studies as an academic discipline. Historical and philological approaches must be left behind, and replaced with Islamic studies that combine philosophical understanding with personal spiritual awareness as two inseparable components in appreciating Islamic phenomena. ${ }^{52}$ In this context, the task of phenomenology is to save holy books, such as the Qur'an, from the "death" of past history, by presenting it in the experience of its adherents. It must be captured from "historical time" and then grafted into the "existential time" where it "lives" and always develops with those who believe in the truth. ${ }^{53}$

Thus, the meaning of the Qur'an is open because it depends on the decisions and choices made by each individual to appreciate it. In what is scripture? Smith states that the true meaning of the Qur'an does not lie in the text, nor does the meaning that is in the mind of God. On the contrary, the meaning of the Koran rests on the understanding, mind and heart of Muslims, because the

${ }^{50}$ Ibid., 142.

${ }^{51}$ Ibid., 141.

52 Ibid., 130. This model of approach might be called by 'Abid al-Jabiri as reason 'irfani in the episteme of Islam. Muḥammad 'Ābid al-Jābirī, Bunya al-'Aql al-'Arabì: Dirāsa Tahlīliyya Naqdiyya li Nizam al-Ma'rifa al-Thaqāfa al- 'Arabiyya (Beirut: Markaz Dirāsāt al-Waḥdah al-'Arabiyyah, 1990), 251-270. See also M. Amin Abdullah, "al-Ta'wil al-'Ilmi: Kearah Perubahan Paradigma Penafsiran Kitab Suci," Al-Jami'ah: Journal of Islamic Studies 39, no. 2 (2001): 359-391.

53 Adam, "The Hermeneutics," 144. 
meaning of the Koran is actually the history of its meanings, is dynamic, creative, complex, and intersects with the lives of its adherents through the centuries in various places. ${ }^{54}$

Another explicit example of a phenomenological approach to Islam is Annemarie Schimmel's work, Deciphering the Signs of God: A Phenomenological Approach to Islam. Schimmel believes that the phenomenological approach is very suitable for understanding Islam better. This approach seeks to enter the path of religion by first examining phenomena and then deeper layers of human response to the divine. With this approach, the inner core of every religion can be reached. ${ }^{55}$ From Scimmel's expression and the search he did, at least it can bring a breath of fresh air that religious tolerance will bring peace. Likewise, Fritjof Schuon emphasizes that the meeting point of religion can be found through perennial philosophy. In addition to Frithjof Schuon, Sayyed Hossein Nasr also expressed his opinion, that he tried to bring together the Islamic religion, philosophy, and science which, according to him, would remain eternal forever. ${ }^{56}$ As a universal religion, Islam is a continuation of religions that were sent down to the apostles of Adam a.s to the Prophet Muhammad. The whole religion is called "al Islam" which in essence is the surrender of totality to God. If the core is the submission to God, then basically all monotheistic religions claim to surrender only to God alone. This means that surrender (al-Islam) is eternal religious teaching and applies forever (religion perennis). The meeting point of religion in the view of perennial philosophy that the philosophy of eternity is a principle found in various religions and traditions. For example, all human beings are happy with the honesty, justice, truth, and values that exist in every religion.

54 Wilfred Cantwell Smith, What Is Scripture? A Comparative Approach (Minneapolis: Fortress Press, 1993), 89-90. See also Wilfred Cantwell Smith, “The True Meaning of Scripture: An Empirical Historian's non-reductionist Interpretation of The Qur'an," International Journal of Middle East Studies 11 (1980): 504. The fourth chapter of What is Scripture? In the beginning was the initial version of the article in this journal.

55 Annemarie Schemmel, Deciphering the Signs of God: A Phenomenological Approach to Islam (Albany: State University of New York Press, 1994), xii.

${ }^{56}$ See, Frithjof Schuon, Islam dan Filsafat Perrenial (Bandung: Mizan, 1998). 


\section{Conclusion}

The difference of thought in understanding phenomenology within the framework of religious studies is not unusual, because there really is no one perfect approach in religious studies. Each has weaknesses. This is closely related to the object itself, namely religion, which is complex and diverse. Therefore, to produce more comprehensive knowledge, a combination of various approaches is needed. The ideal combination is that which takes a circular pattern, not parallel, let alone linear.

The fundamental difference between dogmatic-normative approaches tends to reinforce barriers and give birth to truth claims because indeed it is built on the assumption of truth and as an effort to understand and believe in the teachings of religion whereas social sciences tend to be reductionists towards religion because they view religion solely as a sociological-anthropological phenomenon.

By looking at the strengths and weaknesses of each approach, a collaboration between the two is needed, especially the fact that is happening now, where the world has entered the era of pluralism and multiculturalism, the advantages of religious phenomenology can help create open, tolerant and respectful adherents differently. Finally, phenomenology in the framework of religious studies is criticized but also still needed to understand the essence of religion itself.

\section{References}

Adam, Charles J. "The Hermeneutics of Henry Corbin." In Approaches to Islam In Religious Studies, edited by Richard C. Martin, 129-150. Tucson: The Arizona State University Press, 1985.

Ahimsa-Putra, Heddy Shri. "Fenomenologi Agama: Pendekatan Fenomenologi untuk Memahami Agama." Walisongo: Jurnal Penelitian Sosial Keagamaan 20, no. 2 (2012): 271-304. http://journal.walisongo.ac.id/index.php/walisongo/article/vie $\mathrm{w} / 200$. 
Allen, Douglas. "Phenomenology of Religion." In The Routledge Companion to the Study of Religion, edited by John R. Hinnells, 182-207. London and New York: Routledge, 2005.

Amin Abdullah, M. "al-Ta'wil al-'Ilmi: Kearah Perubahan Paradigma Penafsiran Kitab Suci." Al-Jami'ah: Journal of Islamic Studies 39, no. 2 (2001): 359-391.

- - . "Mempertautkan Ulum al-Din al-Fikr al-Islamy dan

Dirasah Islamiyah." Paper presented at the Workshop Pembelajaran Inovatif Berbasis Integrasi-Interkoneksi, Yogyakarta, 2008.

- - . Studi Agama: Nornativitas atau Historisitas? Yogyakarta: Pustaka Pelajar, 2004.

Anonym. "Phenomenology of Religion." Wikipedia, 2019. Accessed February 18, 2019. https://en.wikipedia.org/wiki/ Phenomenology_of_religion.

Arkoun, Mohamed. Ayna Huwa al-Fikr al-Mu'āshir. Beirut: Dār alSaqi, 1992.

Bertens, K. Filsafat Barat Abad XX: Inggris-Jerman. Jakarta: Gramedia Pustaka Utama, 1990.

Bleicher, Josef. Contemporary Hermeneutics: Hermeneutics as Method, Philosophy and Critique. London and New York: Routledge, 1980.

Conant, James B. Modern Science and Modern Man. Garden City, New York: Doubleday Company, 1954.

Cox, James L. A Guide to the Phenomenology of Religion: Key Figures, Formative Influences and Subsequent Debates. New York: T\&T Clark International, 2006.

- - - Expressing the Sacred: An Introduction to the Phenomenology of Religion. Harare: University of Zimbabwe, 1992.

Dhavamony, Mariasusai. Phenomenology of Religion. Translated by Drikarya Religious Study Team. Yogyakarta: Kanisius, 1995.

Ekeke, Emeka Charles, and Chike Ekeopara. "Phenomenological Approach to the Study of Religion: A Historical Perspective." European Journal of Scientific Research 44, no. 2 (August 2010): 266-274.

Erricker, Clive. "Pendekatan Fenomenologis." In Aneka Pendekatan Studi Agama, edited by Peter Connolly, translated by Imam Khoiri. Yogyakarta: LKiS, 2002. 
al-Jābirī, Muhạmmad 'Ābid. Bunya al-'Aql al-'Arabī: Dirāsa Tahlīliyya Naqdiyya li Nizam al-Ma'rifa al-Thaqāfa al- 'Arabiyya. Beirut: Markaz Dirāsāt al-Waḥdah al-'Arabiyyah, 1990.

Martin, Richard C. Approaches to Islam in Religious Studies. Michigan: University of Arizona Press, 1985.

Moustakas, Clark. Phenomenological Research Methods. London: Sage Publications Inc, 1994.

Mudzhar, Atho. Pendekatan Studi Islam dalam Teori dan Praktik. Yogyakarta: Pustaka Pelajar, 2007.

Muhadjir, Noeng. Metodologi Penelitian Kualitatif. Yogyakarta: Rake Sarasin, 1989.

Rapar, Jan Hendrik. Pengantar Filsafat. Yogyakarta: Kanisius, 1996. Schemmel, Annemarie. Deciphering the Signs of God: A Phenomenological Approach to Islam. Albany: State University of New York Press, 1994.

Schuon, Frithjof. Islam dan Filsafat Perrenial. Bandung: Mizan, 1998. Smith, Wilfred Cantwell. "The True Meaning of Scripture: An Empirical Historian's Non-Reductionist Interpretation of The Qur'an." International Journal of Middle East Studies 11 (1980).

- - - What Is Scripture? A Comparative Approach. Minneapolis: Fortress Press, 1993.

Waardenburg, Jacques. Classical Approach to the Study of Religion. Paris, Mouton: The Hague, 1973. 